\title{
Phosphorylation of carboxypeptidase B1 protein regulates $\beta$-cell proliferation
}

\author{
SEONG-LAN YU ${ }^{1 *}$, SEUNGYUN HAN ${ }^{2 *}$, HONG RYE KIM ${ }^{3 *}$, JONG WOO PARK $^{4}$, \\ DONG IL JIN ${ }^{3}$ and JAEKU KANG ${ }^{1,5}$ \\ Departments of ${ }^{1}$ Pharmacology and ${ }^{2}$ Anatomy, College of Medicine, Konyang University, Daejeon 35365; \\ ${ }^{3}$ Department of Animal Science and Biotechnology, Chungnam National University, Daejeon 34134; \\ ${ }^{4}$ Department of Pharmacology, SungKyunKwan University, Suwon 16419; ${ }^{5}$ Myunggok Medical Research Institute, \\ College of Medicine, Konyang University, Daejeon 35365, Republic of Korea
}

Received September 20, 2016; Accepted September 11, 2017

DOI: 10.3892/ijmm.2017.3141

\begin{abstract}
A reduction in pancreatic islet $\beta$-cells leads to the onset of diabetes. Hence, the identification of the mechanisms inducing $\beta$-cell proliferation is important for developing a treatment course against the disease. It has been well established that post-translational modifications (PTMs) of proteins affect their functionality. In addition, PTMs have been suggested to play important roles in organ regeneration. Therefore, in this study, we investigated PTMs associated with pancreatic regeneration using two-dimensional electrophoresis. Four carboxypeptidase $\mathrm{B} 1$ (CPB1) proteins were identified at different isoelectric points, with the same molecular weight. The motif of CPB1 PTMs was identified by mass spectrophotometry, and the downregulation of $\mathrm{CPB} 1$ phosphorylation in pancreatectomy was confirmed. The dephosphorylation of CPB1 induced $\beta$-cell proliferation. We thus surmise that the altered PTM of CPB1 is associated with pancreatic regeneration.
\end{abstract}

\section{Introduction}

The loss of $\beta$-cell mass in pancreatic islets is closely associated with type 1 and 2 diabetes mellitus. The regeneration of $\beta$-cells for curative treatment of the disease is an important topic of research. New $\beta$-cells are derived from either exogenous sources, such as stem cells or endogenous sources, such as facultative pancreatic progenitors (1-3). Pancreatic injury models (4-7) have suggested several endogenous sources for $\beta$-cell regeneration. Surviving $\beta$-cells may generate new $\beta$-cells

Correspondence to: Dr Jaeku Kang, Department of Pharmacology, College of Medicine, Konyang University, 158 Gwanjeodong-ro, Seo-gu, Daejeon 35365, Republic of Korea

E-mail: jaeku@konyang.ac.kr

${ }^{*}$ Contributed equally

Key words: pancreatic islet $\beta$-cells, post-translational modification, carboxypeptidase $\mathrm{B} 1$, pancreatic regeneration by self-duplication (8), and new $\beta$-cells may arise through transdifferentiation from other pancreatic cells, such as $\alpha$ - and $\delta$-cells $(9,10)$. Moreover, $\beta$-cell neogenesis may develop from multipotent pancreatic progenitor cells $(11,12)$. These studies indicate the plasticity of the pancreas. However, the molecular mechanisms of $\beta$-cell neogenesis are not well known.

A number of studies have identified genes differentially expressed in pancreatic neogenesis by using 'omics' methods, such as cDNA microarray analysis and two-dimensional electrophoresis (2-DE) (13-18). De León et al suggested endoderm transcription factor Foxa2 (also known as HNF3 $\beta$ ) as a potential candidate for the improvement of pancreatic growth and function (15). Moreover, lymphocyte cytosolic protein 1 (LCP1), which is upregulated by partial pancreatectomy, has been suggested as an important protein for pancreatic regeneration owing to an increase in pancreatic cell proliferation and regulation of islet markers (18). In addition, various transcription factors, such as neurogenin 3 (19), paired related homeobox 1 (Prrx1) (20) and pancreatic and duodenal homeobox 1 (Pdx1) (21) regulate pancreatic regeneration. However, protein activity or function is regulated by the expression level, as well as post-translational modifications (PTMs). Mutations of PTM sites cause various diseases (22); in particular, differences in PTMs between chronic pancreatitis and non-pancreatitis have been reported (23). Pdx1 is known to be an important regulator of $\beta$-cell maturation, and its activity is a prerequisite for the regulation of blood glucose homeostasis. Various studies have suggested that Pdx1 activity is regulated by phosphorylation as one of the types of PTMs (21,24-28). Frogne et al recently identified a single phosphorylation site in Pdx1 by isoelectric focusing (IEF) (29). In a partial hepatectomy model, Yes-associated protein (YAP) activity was found to regulate liver regeneration by phosphorylation (30). Moreover, the phosphorylation of RelA (p65), a subunit of nuclear factor $-\kappa \mathrm{B}(\mathrm{NF}-\kappa \mathrm{B})$, has been reported as an important mechanism in liver regeneration and cancer (31). Therefore, the identification of PTM alterations during injury and regeneration may provide novel mechanistic insight into organ regeneration. In this study, to analyze the potential association between PTMs and $\beta$-cell replication, we investigated PTMs associated 
with pancreatic regeneration using 2-DE analysis and further examined the tyrosine phosphorylation level of CPB1.

\section{Materials and methods}

Partial pancreatectomy. To investigate proteins associated with pancreatic regeneration following pancreatectomy, 8-week-old male Sprague-Dawley rats (Daehan Experimental Animals, Seoul, Korea) were anesthetized with isoflurane (Santa Cruz Animal Health ${ }^{\circledR}$, Paso Robles, CA, USA) and divided into 3 treatment groups as follows: partial pancreatectomy $(n=2$; approximately $90 \%$ pancreatectomy), sham surgery $(n=2)$ and no surgery $(\mathrm{n}=2)$. The animals were allowed free access to standard diet and water before and after the operation. Partial pancreatectomy was executed according to BonnerWeir et al (32). In brief, 8-week-old male Sprague-Dawley rats (Daehan Experimental Animals) were anesthetized with $3 \%$ isoflurane in oxygen $\left(\mathrm{O}_{2}\right)$ /nitrous oxide $\left(\mathrm{N}_{2} \mathrm{O}\right)$ mixtures, and $90 \%$ of the pancreatic tissue was then removed by gentle abrasion with cotton swabs, leaving the tissue between the common bile duct and the loop of the duodenum intact. For sham operation, the same surgical procedure was carried out without the removal of pancreatic tissue. On the 3rd day after surgery, the remnant pancreatic tissues were isolated under inhaled anesthesia (3\% isoflurane in $\mathrm{O}_{2} / \mathrm{N}_{2} \mathrm{O}$ mixture) and the rats were then euthanized. The tissues were fixed with neutral buffered formalin (NBF) for histological examination, and immediately stored at $-80^{\circ} \mathrm{C}$. The study protocol was approved by the Institutional Animal Care and Use Committee (IACUC) at Konyang University in accordance with the National Institutes of Health (NIH) Guidelines for the Care and Use of Laboratory Animals.

2-DE. Isolated pancreatic tissues were solubilized using a previously described method (33). Solubilized proteins were quantified with a Bradford protein assay kit (Bio-Rad,Hercules, CA, USA) and then stored at $-80^{\circ} \mathrm{C}$ until use. For resolution across the $\mathrm{pH} 4-7$ range, $1 \mathrm{mg}$ of protein extracted from the sham-operated and pancreatectomized pancreases was mixed with modified rehydration buffer [6 $\mathrm{M}$ urea, $2 \mathrm{M}$ thiourea, 4\% CHAPS, $2.5 \%$ DTT, $10 \%$ isopropanol, $5 \%$ glycerol and $2 \%$ immobilized $\mathrm{pH}$ gradient (IPG) buffer $\mathrm{pH} 4-7$ ], loaded into a cup on the anodic side of a pH 4-7 IPG strip (GE Healthcare Bio-Sciences, Pittsburgh, PA, USA), and incubated for $12 \mathrm{~h}$. Following rehydration, first-dimension IEF was performed on a Multiphor II IEF system (GE Healthcare Bio-Sciences). To separate the second dimension, an equilibrated IPG gel strip was placed on an 8-16\% linear gradient SDS polyacrylamide gel and the gels were subjected to electrophoresis using the Ettan-DALT system (GE Healthcare Bio-Sciences). After 2-DE, the gels were stained using colloidal Coomassie brilliant blue (CBB) G-250 (Sigma-Aldrich, St. Louis, MO, USA). The stained gel was scanned with a GS-710 calibrated imaging densitometer (Bio-Rad), and proteins differentially expressed between pancreatectomized and sham operation samples were identified using the Melanie III image analysis software (Swiss Institute for Bioinformatics, Geneva, Switzerland). Two-DE analysis was performed three times independently. Differences among protein spots were analyzed using a two-way Student's t-test.
Matrix-assisted laser desorption/ionization time-of-flight mass spectrometry (MALDI-TOF/MS) and protein identification. For the identification of differentially expressed proteins, MALDI-TOF/MS analysis of selected spots was performed as previously described (33). Selected spots sliced from the gel were stained with $\mathrm{CBB}$ and then digested with trypsin. Extracted peptides were subjected to MALDI-TOF/MS analysis on a Voyager DE-STR MALDI-TOF mass spectrometer (Applied Biosystems, Foster City, CA, USA). All acquired spectra of samples were processed using Voyager ${ }^{\mathrm{TM}} 5.1$ software (Applied Biosystems) in the default mode. Averages of 500 spectra were obtained for each sample, and scans were performed twice. Spectra were calibrated automatically upon acquisition using an external 3-point calibration. Peaks were manually assigned using the DATA Explorer ${ }^{\mathrm{TM}}$ software package (Applied Biosystems), and spectra were used to search against non-redundant protein sequence databases available online (SWISS-PROT and/or NCBInr Data Bank). The peptide mass fingerprinting data were applied to ProFound and MASCOT search engines (http://prowl.rockefeller.edu/; http:// www.matrixscience.com/search_form_select.html) for protein identification based on ProFound and MASCOT scores. The $\mathrm{Z}$ score of ProFound is the distance to the population mean in units of the standard deviation.

Western blot analysis. Pancreatic tissues and cell lines were lysed using RIPA buffer containing $50 \mathrm{mM}$ Tris-HCl (pH 7.4), $1 \%$ NP-40, $0.25 \%$ sodium deoxycholate, $150 \mathrm{mM}$ $\mathrm{NaCl}, 1$ mM EDTA, and protease inhibitor cocktail (Roche, Basel, Switzerland). To investigate differences in CPB1 phosphorylation, we performed immunoprecipitation. Briefly, $800 \mu \mathrm{g}$ of lysate was precleared with protein A-agarose for $2 \mathrm{~h}$ at $4^{\circ} \mathrm{C}$. The supernatant was incubated with anti-CPB1 (GenWay Biotech, San Diego, CA, USA) by shaking overnight at $4^{\circ} \mathrm{C}$, followed by incubation with protein A-agarose for $2 \mathrm{~h}$. The beads were resuspended in $2 \mathrm{X}$ sample buffer and boiled for $10 \mathrm{~min}$. The proteins were resolved on $10 \%$ sodium dodecyl sulfate-polyacrylamide gel electrophoresis (SDS-PAGE) gels and transferred onto polyvinylidene difluoride membranes (Millipore, Billerica, MA, USA). Immunoblots were incubated in 5\% skim milk (Difco, Franklin Lakes, NJ, USA) for $1 \mathrm{~h}$ and probed with anti-tyrosine (1:1000; sc-7020; Santa Cruz Biotechnology, Inc., Dallas, TX, USA), anti-CPB1 (1:1000; GWB-31DED0; GenWay Biotech, San Diego, CA, USA) and anti- $\beta$-actin (1:3000; sc-47778; Santa Cruz Biotechnology, Inc.) primary antibodies overnight, followed by incubation with a horseradish peroxidase-conjugated anti-mouse or anti-rabbit secondary antibody for $2 \mathrm{~h}$. Immunoreactive bands were detected using an enhanced chemiluminescence kit (ECL; Thermo Scientific, Waltham, MA, USA).

Immunohistochemical analysis. To identify alterations in CPB1 protein phosphorylation levels in the pancreas following pancreatectomy, the sham-operated and partially pancreatectomized pancreases were removed and fixed with NBF overnight at room temperature. Fixed tissues were embedded in paraffin and the paraffin blocks were sliced at $5 \mu \mathrm{m}$ thicknesses using a tissue microtome (Leica, Nussloch, Germany). The slides were blocked with $10 \%$ goat serum (Vector Laboratories, Inc., Burlingame, CA, USA) and incubated with phospho-Tyr antibody (sc-7020; Santa 
A

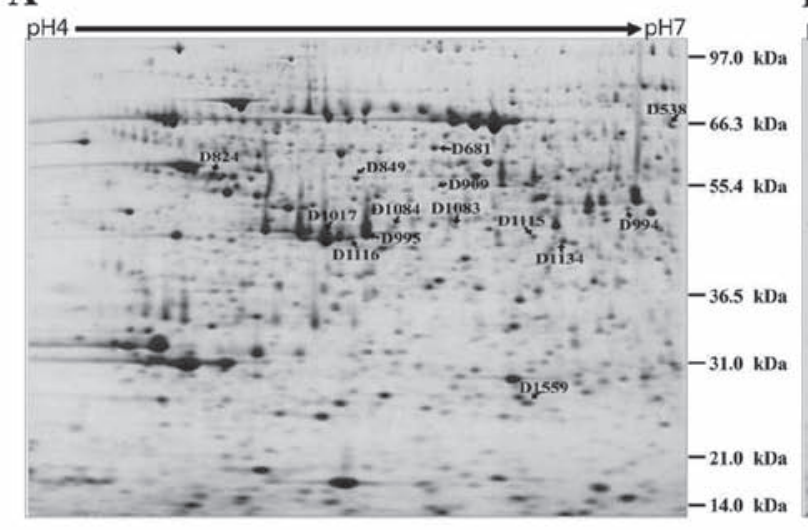

C

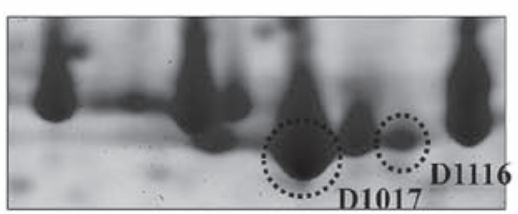

B

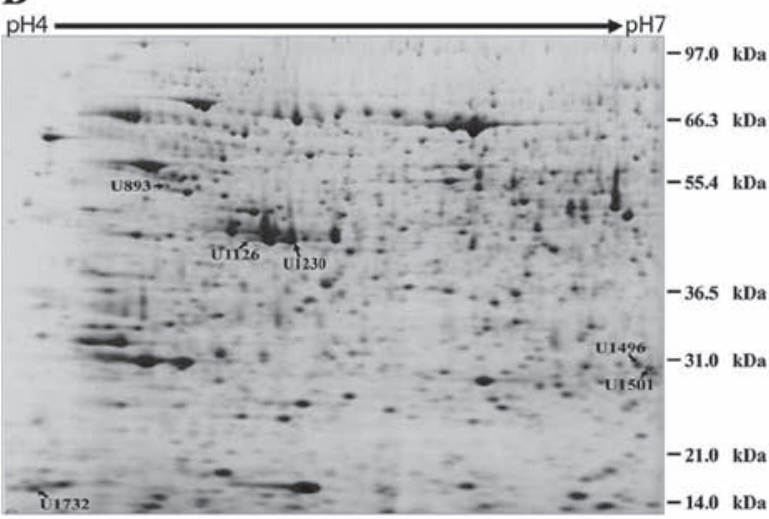

D

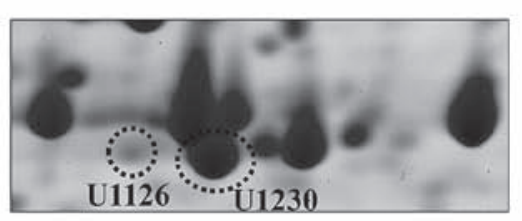

Figure 1. Two-dimensional electrophoresis (2-DE) profiling of pancreatic proteins in (A and C) sham-operated and (B and D) partially pancreatectomized rats. The arrows in (A) indicate downregulated proteins in rats subjected to partial pancreatectomy vs. the sham-operated rats, and the arrows in (B) indicate upregulated proteins in rats subjected to partial pancreatectomy vs. the sham-operated rats. (C and D) Carboxypeptidase B1 (CPB1) proteins of different isoelectric points on the 2-DE profile.

Cruz Biotechnology, Inc.), and CPB1 antibody (GWB-31DED0; GenWay Biotech) as primary antibodies at $4^{\circ} \mathrm{C}$ overnight and then with Cy2-conjugated goat anti-rabbit $\operatorname{IgG}(111-225-144)$ and Cy3-conjugated goat anti-mouse IgG (115-165-146) secondary antibodies (both from Jackson Immuno Research, West Grove, PA, USA) as secondary antibodies at room temperature for $1 \mathrm{~h}$. Nuclei were counterstained with 4',6'-diamidino-2-phenylindole dihydrochloride (Molecular Probes, Waltham, MA, USA). The stained cells were examined under a confocal microscope (Carl Zeiss, Oberkochen, Germany).

DNA constructs and mutagenesis. Total RNA was isolated from the rat pancreases using TRI Reagent ${ }^{\circledR}$ (Ambion, Waltham, MA, USA) according to the manufacturer's instructions. Approximately 1.2 kb cDNA of CPB1 (NM_012533.1) was obtained from rat pancreatic RNA by RT-PCR using the following primers: 5'-GCC GCC ACC ATG TTG CTG CTA CTG GCC CT-3' (forward) and 5'-GGT CCA ATT GGT CAA CAC ACC CA-3' (reverse), and the cDNA was cloned (CPB1OE) into the EcoRI site of pcDNA3-EGFP (Addgene, Cambridge, MA, USA). Mutations of 6 tyrosine sites of the CPB1 protein (Y298F, Y304F, Y310F, Y312F, Y314F and Y316F) were introduced (CPB1OE-mutY) using the QuikChange ${ }^{\circledR}$ Site-Directed Mutagenesis kit (Stratagene, La Jolla, CA, USA) according to the manufacturer's instructions. Mutated sites were confirmed by sequencing.

Cell culture and transfection. RIN-m insulinoma cells obtained from the American Type Culture Collection (ATCC, Manassas, VA, USA) were cultured in RPMI-1640 (ATCC) supplemented with $10 \%$ fetal bovine serum (Gibco, Carlsbad, CA, USA) and $1 \%$ penicillin/streptomycin (Lonza, Basel, Switzerland). The cells were maintained at $37^{\circ} \mathrm{C}$ in a humidified atmosphere containing $5 \% \mathrm{CO}_{2}$. The RIN-m cells were transfected with control pcDNA3-EGFP (Addgene), a rat $C P B 1$ full-length cDNA vector (CPB1OE) and mutant rat $C P B 1$ full-length cDNA vector (CPB1OE-mutY) using Lipofectamine 2000 (Invitrogen, Carlsbad, CA, USA) according to the manufacturer's instructions. To establish stable cell lines, transfected clones were cultured in selective media containing $150 \mu \mathrm{g} / \mathrm{ml}$ G418 (Sigma-Aldrich).

Cell viability. To identify the association between the phosphorylation of CPB1 protein and cell viability, stable cell lines (control, CPB1OE and CPB1OE-mutY) were seeded in 12-well plates at a density of $5 \times 10^{5}$ cells/well. Cell viability was measured at 6,24 and $48 \mathrm{~h}$. Cells were collected and mixed with $0.4 \%$ trypan blue stain solution (Gibco), after which unstained cells were counted under a microscope (Olympus, Tokyo, Japan).

Statistical analyses. All graphed data are presented as the means \pm standard deviation. The results were analyzed using analysis of variance (ANOVA) or a Student's t-test. P-values of $<0.05$ and $<0.01$ were considered to indicate statistically significant and highly statistically significant differences, respectively.

\section{Results}

Identification of proteins up-or downregulated by partial pancreatectomy. To identify proteins associated with pancreatic regeneration, we compared proteins in pancreatic tissues obtained from rats at 3 days after partial pancreatectomy with those of sham-operated rats by 2-DE analysis with IEF gel electrophoresis on $\mathrm{pH}$ 4-7 linear IPG strips. Independent experiments were each carried out in duplicate. Melanie III detected differential intensity in 20 spots; 14 proteins were downregulated and 6 were upregulated in the rats subjected to compared with the sham-operated rats (Fig. 1A and B). 
Table I. Identification of proteins differentially expressed in partial pancreatectomy in the $\mathrm{pH} 4-7$ range.

\begin{tabular}{|c|c|c|c|c|c|c|}
\hline Spot ID & Est'd Z & Accession no. & Protein information & $\begin{array}{l}\text { Coverage } \\
(\%)\end{array}$ & $\mathrm{pI}$ & $\mathrm{kDa}$ \\
\hline \multicolumn{7}{|c|}{ Downregulated proteins } \\
\hline D538 & 2.39 & NP_001101847.2 & $\begin{array}{l}\text { Phosphoenolpyruvate carboxykinase } 2 \\
\text { (mitochondrial) }\end{array}$ & 33 & 8.4 & 71.79 \\
\hline D681 & 2.4 & NP_599153.2 & Serum albumin precursor & 43 & 6.1 & 71.23 \\
\hline D824 & 1.55 & AAA40788.1 & $\alpha$-1-antitrypsin precursor & 50 & 5.7 & 46.03 \\
\hline D849 & 2.39 & AAA41082.1 & Vitamin D-binding protein & 46 & 5.8 & 55.49 \\
\hline D909 & 1.85 & EDL88549.1 & $\begin{array}{l}\text { Rattus norvegicus (Norway rat) albumin, } \\
\text { isoform CRA_a }\end{array}$ & 27 & 6.8 & 53.46 \\
\hline D994 & 2.22 & NP_001004206.1 & Proliferation-associated protein $2 \mathrm{G} 4$ & 47 & 6.4 & 44.07 \\
\hline D995 & 2.4 & P00731.2 & Carboxypeptidase A1 & 40 & 5.5 & 47.19 \\
\hline D1017 & 2.18 & NP_036665.1 & Carboxypeptidase B precursor & 26 & 5.4 & 48 \\
\hline D1083 & 1.47 & NP_001101857.2 & $\begin{array}{l}\text { Succinyl-CoA ligase [ADP-forming] subunit } \beta \text {, } \\
\text { mitochondrial }\end{array}$ & 33 & 6.1 & 47.8 \\
\hline D1084 & 1.82 & NP_599153.2 & Serum albumin precursor & 24 & 6.1 & 71.23 \\
\hline D1115 & 2.3 & EDL77312.1 & $\begin{array}{l}\text { Rattus norvegicus (Norway rat) rCG25777, } \\
\text { isoform CRA_a }\end{array}$ & 41 & 5.9 & 42.36 \\
\hline D1116 & 2.3 & NP_036665.1 & Carboxypeptidase B precursor & 49 & 5.4 & 48 \\
\hline D1134 & 2.4 & NP_036724.1 & $\begin{array}{l}\text { Isovaleryl-CoA dehydrogenase, } \\
\text { mitochondrial precursor }\end{array}$ & 34 & 8.5 & 46.44 \\
\hline D1559 & 2.2 & NP_476484.1 & Protein DJ-1 & 71 & 6.3 & 20.24 \\
\hline \multicolumn{7}{|c|}{ Upregulated proteins } \\
\hline U893 & 2.3 & NP_112402.1 & Vimentin & 46 & 5.1 & 53.75 \\
\hline U1126 & 2.04 & NP_036665.1 & Carboxypeptidase B precursor & 39 & 5.4 & 48 \\
\hline U1230 & $55^{\mathrm{b}}$ & NP_036665.1 & Carboxypeptidase B precursor & 39 & 5.4 & 48 \\
\hline U1496 & 2.36 & XP_345279.4 & Amylase $2 \mathrm{a} 5$, pancreatic & 27 & 9.3 & 50.58 \\
\hline U1501 & 2.36 & NP_445742.1 & Phosphoglycerate mutase 1 & 56 & 7.1 & 28.97 \\
\hline U1732 & 2.16 & XP_573831.1 & Ribosomal protein P2-like & 84 & 4.4 & 11.69 \\
\hline
\end{tabular}

a $\mathrm{Z}$ score is the distance to the population mean in units of standard deviation. It also corresponds to the percentile of the search in the random match population. Conceptually, this 95 th percentile is different from $95 \%$ confidence that the search is a correct identification. The following is a list for Z score and its corresponding percentile in an estimated (Est'd) random match population: [(Z: percentile) 1.282:90, 1.645:95.0, 2.326:99.0, 3.090:99.9)]. ${ }^{b}$ Mowse score is $-10 x \log (\mathrm{P})$, where $\mathrm{P}$ is the probability that the observed match is a random event. Protein scores $>51$ are significant $(\mathrm{p}<0.05)$.

The differentially expressed proteins were identified by MALDI-TOF/MS (Table I). Among the identified proteins, phosphoenolpyruvate carboxykinase 2 (PCK2) has been reported to be differentially expressed in pancreatectomy (18). Amylase is also specifically expressed in the pancreas (34). Succinate-CoA ligase ADP-forming $\beta$ subunit (Sucla2) and isovaleryl-CoA dehydrogenase (Ivd), which are involved in the mitochondrial Krebs cycle, were downregulated upon pancreatectomy. Mitochondrial function and plasticity are associated with glucose circulation (35). Interestingly, carboxypeptidase $\mathrm{B}$ (CPB1) precursor protein was identified from 4 spots at different PIs among the 20 spots (Fig. 1C and D). Therefore, we selected CPB1 for further study.

Post-translational modification of CPB1. PTMs of proteins such as phosphorylation or dephosphorylation induce shifts in the PI and regulate the functional activity of enzymes (36).
Therefore, we investigated alterations in the phosphorylation level of CPB1 in normal, sham-operated and partially pancreatectomized pancreases using the immunoprecipitation method. Phosphorylation of tyrosine residues of the CPB1 protein was significantly reduced by partial pancreatectomy (Fig. 2A). Immunohistochemistry confirmed that the phosphorylation of the tyrosine residue of CPB1 in partial pancreatectomy decreased (Fig. 2B). These results suggested that PTM of the CPB1 protein may be associated with pancreatic regeneration.

Reduced phosphorylation of CPB1 induces pancreatic cell proliferation. An increase in $\beta$-cell mass is derived from $\beta$-cell neogenesis, proliferation and hypertrophy, and $\beta$-cell proliferation gradually declines with age (37). However, partial pancreatectomy models in mice and rats have been reported to enhance $\beta$-cell replication (38). Therefore, we investigated 

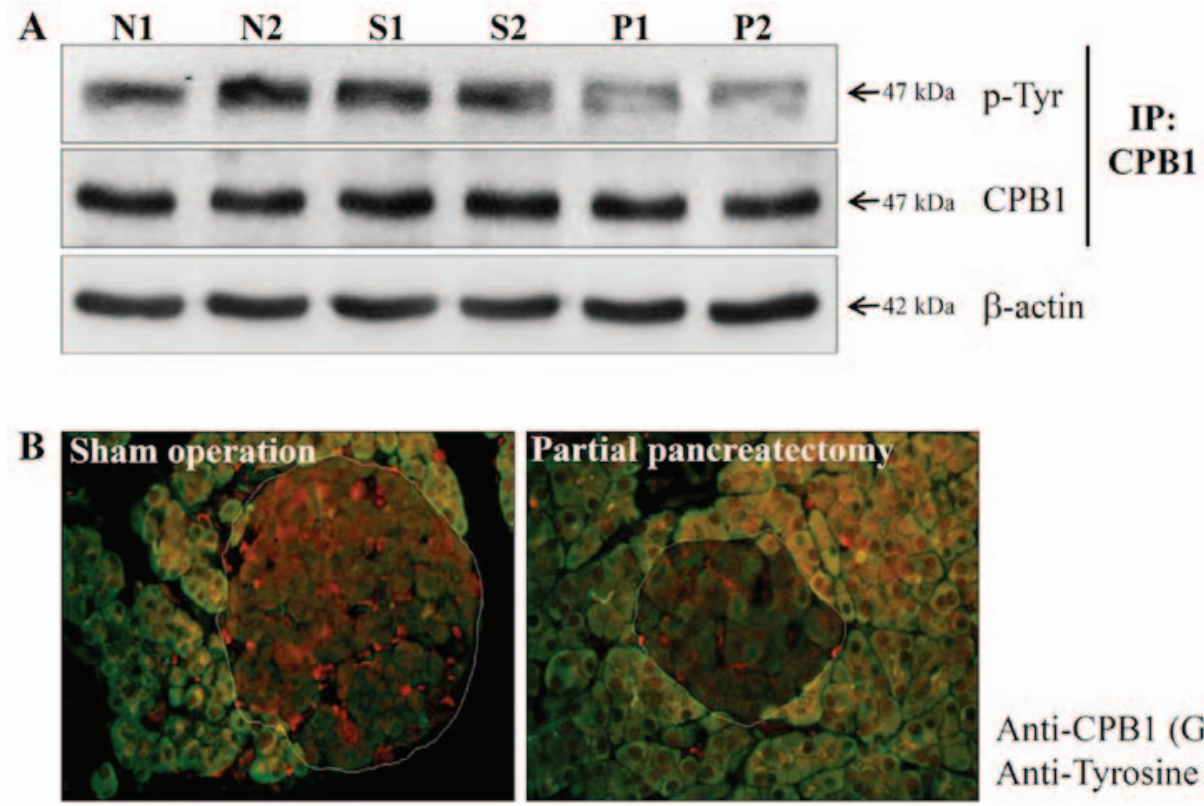

Anti-CPB1 (Green)

Anti-Tyrosine (Red)

Figure 2. Phosphorylation of carboxypeptidase B1 (CPB1) protein is decreased by partial pancreatectomy. (A) The phosphorylation levels of CPB1 protein among normal $(\mathrm{N})$, sham-operated $(\mathrm{S})$, and partial pancreatectomized $(\mathrm{P})$ pancreases were analyzed by western blotting after immunoprecipitation with anti-CPB1. (B) The phosphorylated tyrosine of CPB1 protein between sham operation and partial pancreatectomy was observed by immunohistochemistry. Images were captured at x200. Green, CPB1 protein; red, phosphorylated tyrosine.

$\mathbf{A}$ Wild type

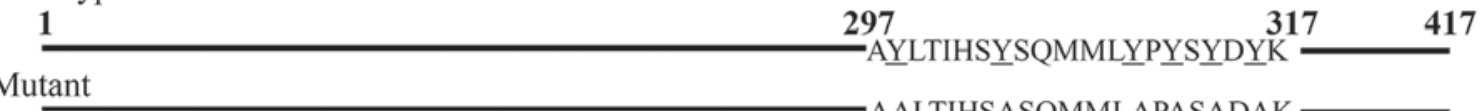

B

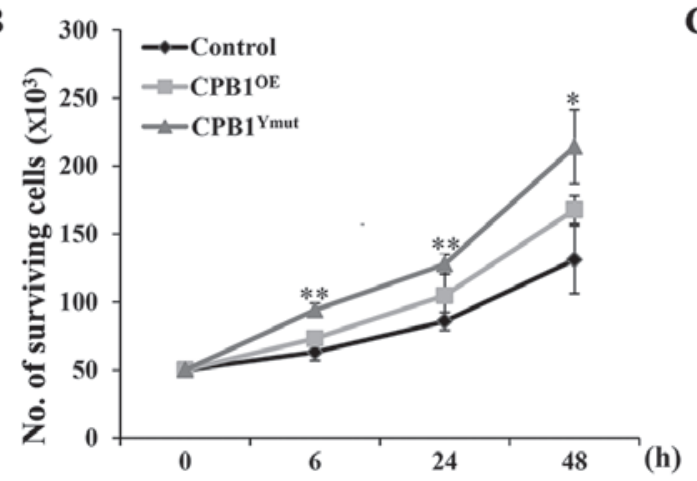

C

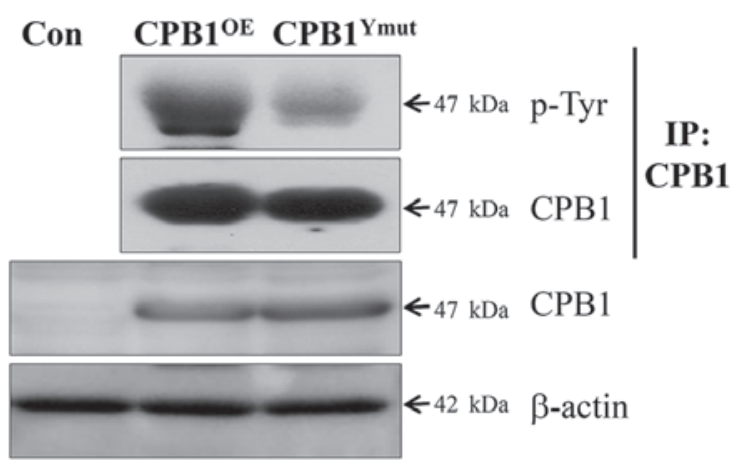

Figure 3. Reduced phosphorylation of carboxypeptidase B1 (CPB1) protein promotes pancreatic cell survival. (A) Schematic diagram representing the part of wild-type CPB1 modified by partial pancreatectomy as identified by mass spectrophotometry. In mutant CPB1, phenylalanine is substituted by tyrosine in the modification site. (B) Overexpression of CPB1 increases pancreatic cell survival, and decreased phosphorylation of CPB1 further increases cell survival. Data represent means \pm SDs of three independent experiments. ${ }^{* *} \mathrm{P}<0.01 ;{ }^{*} \mathrm{P}<0.05$. (C) CPB1-overexpressing stable cell lines were identified by western blot analysis, and the phosphorylation levels of wild-type and mutant proteins were investigated by immunoprecipitation.

whether the PTM of CPB1 was involved in $\beta$-cell replication. First, the PTM region of the CPB1 protein was mutated by phenylalanine-to-tyrosine substitution to reduce the phosphorylation level (Fig. 3A). Mutations at 6 sites (Y298F, Y304F, Y310F, Y312F, Y314F and Y316F) were confirmed by sequencing.

Rat $\beta$-cell lines overexpressing wild-type or mutant CPB1 were established. CPB1-overexpressing (CPB1OE) cell lines showed higher proliferation than the control (Fig. 3B). In addition, reduced tyrosine phosphorylation in the CPB1OEmutY cell line resulted in increased proliferation compared to that in CPB1OE cells. To confirm the reduced tyrosine phosphorylation of CPB1, we performed immunoprecipitation of the CPB1 antibody and detected phosphorylated CPB1 by western blotting. Tyrosine phosphorylation of CPB1 in CPB1OE-mutY cell lines decreased (Fig. 3C). Therefore, we clearly demonstrated that the dephosphorylation of CPB1 was associated with pancreatic regeneration. 


\section{Discussion}

In the present study, we applied 2-DE analysis to investigate PTMs of proteins related to pancreatic regeneration. However, the present study has certain limitations, one of these being the small sample size. Although the experimental group was not sufficiently large enough for a comprehensive protein hunt, we used it only to screen for proteins differentially expressed in pancreatectomy, and we do not claim complete coverage. We observed 20 spots, including 4 CPB1 spots having different PIs, and we confirmed the modification of CPB1 by MALDI-TOF/MS. Carboxypeptidases have been examined for their functions in digestion, and several studies on the synthesis of mature proteins or their regulation of biological processes are underway. On the basis of their active site mechanism, carboxypeptidases are divided into three classes: metallocarboxypeptidases, serine carboxypeptidases, and cysteine carboxypeptidases. CPB is a metallocarboxypeptidase, and it has two isoforms: CPB1 and CPB2 (39). CPB was the first pancreas-specific protein identified from proteins differentially expressed between the normal pancreas and pancreatic carcinoma (40). Moreover, CPB has been suggested as a serum marker for acute pancreatitis and dysfunction of pancreatic transplants (41-43).

$\mathrm{CPB} 1$ is secreted as a procarboxypeptidase form, together with other pancreatic proenzymes, and is converted to the active form through the action of trypsin (44-46). Only few PTMs of CPB1 have been reported thus far. 3-Nitrotyrosine has been reported to be a type of oxidative PTM of CPB1, and nitration of tyrosine plays an important role in regulating enzyme activity. Sites of tyrosine nitration are located at Try-198 and Tyr-248 in the catalytic site of CPB1 $(47,48)$. However, there is no report on the association between PTMs of CPB1 and pancreatic regeneration. We identified and confirmed PTMs of CPB1 by 2-DE and mass spectrometry that may be associated with partial pancreatectomy. In islet cells and $\beta$-cells, AMP-activated protein kinase (AMPK) regulates enzyme activity by phosphorylation, and active AMPK inhibits insulin secretion and proinsulin gene expression (49). Hussain et al suggested that the phosphorylation of CREB-binding protein involved in the cyclic AMP signaling pathway affects $\beta$-cell proliferation (50). Moreover, Rab-GTPase-activating protein, having a critical role in glucose and lipid metabolism, regulates phosphorylation by glucose in rat $\beta$-cells (51). Khoury et al reported a statistical analysis of PTMs in the SWISS-PROT database; phosphorylation is the most widely experimentally observed PTM (52). Moreover, protein phosphorylation plays important roles in activation, inactivation, or modification of protein function. Therefore, we compared CPB1 phosphorylation levels between pancreases from sham-operated and partially pancreatectomized mice using immunoprecipitation and immunohistochemistry. We confirmed a reduction in CPB1 phosphorylation by partial pancreatectomy. To our knowledge, this study is the first to identify the association between CPB1 dephosphorylation and pancreatic regeneration. As exact phosphorylation sites of CPB1 have not been reported to date, we substituted 6 anticipated tyrosines for phenylalanine and focused on the PTMs of CPB1 and pancreatic regeneration. We found that CPB1 dephosphorylation affected $\beta$-cell proliferation. However, the identification of the exact phosphorylation sites and mechanisms warrants further studies. Glucagon-like peptide-1, cyclin D1, parathyroid hormone-related protein (PTHrP), hepatocyte growth factor/c-Met signaling, and double-stranded RNA-dependent protein kinase have been identified as candidate proteins functioning in pancreatic $\beta$-cell proliferation (53-57). $5 '-N$-ethylcarboxyamidoadenosine, an adenosine kinase inhibitor, and domperidone, a dopamine D2 receptor antagonist, were recently identified as small-molecule enhancers of $\beta$-cell proliferation for the treatment of diabetes $(58,59)$. In addition, injection of amino-terminal peptides of PTHrP enhanced $\beta$-cell proliferation in partially pancreatectomized mice (60). Therefore, as a next step, it needs to be determined if peptides containing the dephosphorylation site of CPB1 indicated in Fig. 3A can enhance $\beta$-cell proliferation in vivo. Diabetes induced by a reduction in pancreatic $\beta$-cells may be treatable by replenishing the $\beta$-cell mass. However, pancreas or islet transplantation has limited applicability owing to difficulties such as shortage of organ donors and immunorejection of the transplanted tissue. Therefore, the identification of $\beta$-cell proliferation mechanisms forms the basis for developing efficient diabetes treatment approaches. In this study, we provided evidence supporting the relevance of $\mathrm{CPB} 1$ phosphorylation in $\beta$-cell proliferation.

\section{Acknowledgements}

This study was supported by the National Research Foundation of Korea Grant funded by the Korean Government (NRF-2012S1A2A1A0129168, NRF-2010-0007110 and NRF-2015R1D1A3A01019948).

\section{References}

1. Seaberg RM, Smukler SR, Kieffer TJ, Enikolopov G, Asghar Z, Wheeler MB, Korbutt G and van der Kooy D: Clonal identification of multipotent precursors from adult mouse pancreas that generate neural and pancreatic lineages. Nat Biotechnol 22: 1115-1124, 2004.

2. D'Amour KA, Bang AG, Eliazer S, Kelly OG, Agulnick AD, Smart NG, Moorman MA, Kroon E, Carpenter MK and Baetge EE: Production of pancreatic hormone-expressing endocrine cells from human embryonic stem cells. Nat Biotechnol 24: 1392-1401, 2006.

3. Kroon E, Martinson LA, Kadoya K, Bang AG, Kelly OG, Eliazer $\mathrm{S}$, Young H, Richardson M, Smart NG, Cunningham J, et al: Pancreatic endoderm derived from human embryonic stem cells generates glucose-responsive insulin-secreting cells in vivo. Nat Biotechnol 26: 443-452, 2008.

4. Lampeter EF, Gurniak M, Brocker U, Klemens C, Tubes M, Friemann J and Kolb H: Regeneration of beta-cells in response to islet inflammation. Exp Clin Endocrinol Diabetes 103 (Suppl 2): 74-78, 1995.

5. Hayashi KY, Tamaki H, Handa K, Takahashi T, Kakita A and Yamashina S: Differentiation and proliferation of endocrine cells in the regenerating rat pancreas after $90 \%$ pancreatectomy. Arch Histol Cytol 66: 163-174, 2003.

6. Kopp JL, Dubois CL, Schaffer AE, Hao E, Shih HP, Seymour PA, Ma J and Sander M: Sox $9^{+}$ductal cells are multipotent progenitors throughout development but do not produce new endocrine cells in the normal or injured adult pancreas. Development 138: 653-665, 2011

7. Criscimanna A, Coudriet GM, Gittes GK, Piganelli JD and Esni F: Activated macrophages create lineage-specific microenvironments for pancreatic acinar- and $\beta$-cell regeneration in mice. Gastroenterology 147: 1106-1118, 2014.

8. Dor Y, Brown J, Martinez OI and Melton DA: Adult pancreatic beta-cells are formed by self-duplication rather than stem-cell differentiation. Nature 429: 41-46, 2004. 
9. Thorel F, Népote V, Avril I, Kohno K, Desgraz R, Chera S and Herrera PL: Conversion of adult pancreatic alpha-cells to betacells after extreme beta-cell loss. Nature 464: 1149-1154, 2010.

10. Chera S, Baronnier D, Ghila L, Cigliola V, Jensen JN, Gu G, Furuyama K, Thorel F, Gribble FM, Reimann F, et al: Diabetes recovery by age-dependent conversion of pancreatic $\delta$-cells into insulin producers. Nature 514: 503-507, 2014.

11. Inada A, Nienaber C, Katsuta H, Fujitani Y, Levine J, Morita R, Sharma A and Bonner-Weir S: Carbonic anhydrase II-positive pancreatic cells are progenitors for both endocrine and exocrine pancreas after birth. Proc Natl Acad Sci USA 105: 19915-19919, 2008.

12. Xu X, D'Hoker J, Stangé G, Bonné S, De Leu N, Xiao X Van de Casteele M, Mellitzer G, Ling Z, Pipeleers D, et al: Beta cells can be generated from endogenous progenitors in injured adult mouse pancreas. Cell 132: 197-207, 2008.

13. Lim HW, Lee JE, Shin SJ, Lee YE, Oh SH, Park JY, Seong JK and Park JS: Identification of differentially expressed mRNA during pancreas regeneration of rat by mRNA differential display. Biochem Biophys Res Commun 299: 806-812, 2002.

14. Shin JS, Lee JJ, Lee EJ, Kim YH, Chae KS and Kim CW: Proteome analysis of rat pancreas induced by pancreatectomy. Biochim Biophys Acta 1749: 23-32, 2005.

15. De León DD, Farzad C, Crutchlow MF, Brestelli J, Tobias J, Kaestner KH and Stoffers DA: Identification of transcriptional targets during pancreatic growth after partial pancreatectomy and exendin-4 treatment. Physiol Genomics 24: 133-143, 2006.

16. Yang M, Liu W, Wang CY, Liu T, Zhou F, Tao J, Wang Y and Li MT: Proteomic analysis of differential protein expression in early process of pancreatic regeneration in pancreatectomized rats. Acta Pharmacol Sin 27: 568-578, 2006.

17. Choi JH, Lee MY, Kim Y, Shim JY, Han SM, Lee KA, Choi YK, Jeon HM and Baek KH: Isolation of genes involved in pancreas regeneration by subtractive hybridization. Biol Chem 391: $1019-1029,2010$

18. Choi JH, Lee MY, Ramakrishna S, Kim Y, Shim JY, Han SM, Kim JY, Lee DH, Choi YK and Baek KH: LCP1 up-regulated by partial pancreatectomy supports cell proliferation and differentiation. Mol Biosyst 7: 3104-3111,2011.

19. Rukstalis JM and Habener JF: Neurogenin3: A master regulator of pancreatic islet differentiation and regeneration. Islets 1 : 177-184, 2009

20. Reichert M, Takano S, von Burstin J, Kim SB, Lee JS, Ihida-Stansbury K, Hahn C, Heeg S, Schneider G, Rhim AD, et al: The Prrx1 homeodomain transcription factor plays a central role in pancreatic regeneration and carcinogenesis. Genes Dev 27: 288-300, 2013

21. Ahlgren U, Jonsson J, Jonsson L, Simu K and Edlund H: beta-cell-specific inactivation of the mouse Ipf $1 / \mathrm{Pdx} 1$ gene results in loss of the beta-cell phenotype and maturity onset diabetes. Genes Dev 12: 1763-1768, 1998.

22. Li S, Iakoucheva LM, Mooney SD and Radivojac P: Loss of post-translational modification sites in disease. Pacific Symposium on Biocomputing. Pac Symp Biocomput: 337-347, 2010.

23. Paulo JA, Kadiyala V, Brizard S, Banks PA, Steen H and Conwell DL: Post-translational modifications of pancreatic fluid proteins collected via the endoscopic pancreatic function test (ePFT). J Proteomics 92: 216-227, 2013.

24. Petersen HV, Peshavaria M, Pedersen AA, Philippe J, Stein R, Madsen OD and Serup P: Glucose stimulates the activation domain potential of the PDX-1 homeodomain transcription factor. FEBS Lett 431: 362-366, 1998

25. Khoo S, Griffen SC, Xia Y, Baer RJ, German MS and Cobb MH: Regulation of insulin gene transcription by ERK1 and ERK2 in pancreatic beta cells. J Biol Chem 278: 32969-32977, 2003

26. Lebrun P, Montminy MR and Van Obberghen E: Regulation of the pancreatic duodenal homeobox-1 protein by DNA-dependent protein kinase. J Biol Chem 280: 38203-38210, 2005.

27. Boucher MJ, Selander L, Carlsson L and Edlund H: Phosphorylation marks IPF1/PDX1 protein for degradation by glycogen synthase kinase 3 -dependent mechanisms. J Biol Chem 281: 6395-6403, 2006

28. Meng R, Al-Quobaili F, Müller I, Götz C, Thiel G and Montenarh M: CK2 phosphorylation of Pdx-1 regulates its transcription factor activity. Cell Mol Life Sci 67: 2481-2489, 2010.

29. Frogne T, Sylvestersen KB, Kubicek S, Nielsen ML and Hecksher-Sørensen J: Pdx1 is post-translationally modified in vivo and serine 61 is the principal site of phosphorylation. PLoS One 7: e35233, 2012.
30. Grijalva JL, Huizenga M, Mueller K, Rodriguez S, Brazzo J, Camargo F, Sadri-Vakili G and Vakili K: Dynamic alterations in Hippo signaling pathway and YAP activation during liver regeneration. Am J Physiol Gastrointest Liver Physiol 307: G196-G204, 2014

31. Moles A, Butterworth JA, Sanchez A, Hunter JE, Leslie J, Sellier H, Tiniakos D, Cockell SJ, Mann DA, Oakley F, et al: A RelA(p65) Thr505 phospho-site mutation reveals an important mechanism regulating NF- $\kappa \mathrm{B}$-dependent liver regeneration and cancer. Oncogene 35: 4623-4632, 2016.

32. Bonner-Weir S, Trent DF and Weir GC: Partial pancreatectomy in the rat and subsequent defect in glucose-induced insulin release. J Clin Invest 71: 1544-1553, 1983.

33. Kim HR, Kang JK, Yoon JT, Seong HH, Jung JK, Lee HM, Sik Park C and Jin DI: Protein profiles of bovine placenta derived from somatic cell nuclear transfer. Proteomics 5: 4264-4273, 2005.

34. Harding JD and Rutter WJ: Rat pancreatic amylase mRNA. Tissue specificity and accumulation during embryonic development. J Biol Chem 253: 8736-8740, 1978.

35. Jelenik T and Roden M: Mitochondrial plasticity in obesity and diabetes mellitus. Antioxid Redox Signal 19: 258-268, 2013

36. Dephoure N, Gould KL, Gygi SP and Kellogg DR: Mapping and analysis of phosphorylation sites: A quick guide for cell biologists. Mol Biol Cell 24: 535-542, 2013.

37. Ackermann AM and Gannon M: Molecular regulation of pancreatic beta-cell mass development, maintenance, and expansion. J Mol Endocrinol 38: 193-206, 2007.

38. Li WC, Rukstalis JM, Nishimura W, Tchipashvili V, Habener JF, Sharma A and Bonner-Weir S: Activation of pancreaticduct-derived progenitor cells during pancreatic regeneration in adult rats. J Cell Sci 123: 2792-2802, 2010.

39. Marinkovic DV, Marinkovic JN, Erdös EG and Robinson CJ: Purification of carboxypeptidase B from human pancreas. Biochem J 163: 253-260, 1977.

40. Pousette A, Fernstad R, Sköldefors H and Carlström K: Novel assay for pancreatic cellular damage: 1. Characterization of protein profiles in human pancreatic cytosol and purification and characterization of a pancreatic specific protein. Pancreas 3 : 421-426, 1988

41. Yamamoto KK, Pousette A, Chow P, Wilson H, el Shami S and French CK: Isolation of a cDNA encoding a human serum marker for acute pancreatitis. Identification of pancreas-specific protein as pancreatic procarboxypeptidase B. J Biol Chem 267: 2575-2581, 1992.

42. Chen CC, Wang SS, Chao Y, Chen SJ, Lee SD, Wu SL, Jeng FS and Lo KJ: Serum pancreas-specific protein in acute pancreatitis. Its clinical utility in comparison with serum amylase. Scand J Gastroenterol 29: 87-90, 1994.

43. Printz H, Siegmund H, Wojte C, Schäfer C, Hesse H, Rothmund M and Göke B: ‘Human pancreas-specific protein' (procarboxypeptidase B): A valuable marker in pancreatitis? Pancreas 10: 222-230, 1995.

44. Burgos FJ, Salvà M, Villegas V, Soriano F, Mendez E and Avilés FX: Analysis of the activation process of porcine procarboxypeptidase B and determination of the sequence of its activation segment. Biochemistry 30: 4082-4089, 1991.

45. Appelros S, Thim L and Borgström A: Activation peptide of carboxypeptidase B in serum and urine in acute pancreatitis. Gut 42: 97-102, 1998

46. Müller CA, Appelros S, Uhl W, Büchler MW and Borgström A: Serum levels of procarboxypeptidase $B$ and its activation peptide in patients with acute pancreatitis and non-pancreatic diseases. Gut 51: 229-235, 2002

47. Sokolovsky M: Porcine carboxypeptidase B. Nitration of the functional tyrosyl residue with tetranitromethane. Eur J Biochem 25: 267-273, 1972

48. Chatterjee S, Lardinois O, Bonini MG, Bhattacharjee S, Stadler K, Corbett J, Deterding LJ, Tomer KB, Kadiiska M and Mason RP: Site-specific carboxypeptidase B1 tyrosine nitration and pathophysiological implications following its physical association with nitric oxide synthase- 3 in experimental sepsis. J Immunol 183: 4055-4066, 2009.

49. da Silva Xavier G, Leclerc I, Salt IP, Doiron B, Hardie DG, Kahn A and Rutter GA: Role of AMP-activated protein kinase in the regulation by glucose of islet beta cell gene expression. Proc Natl Acad Sci USA 97: 4023-4028, 2000.

50. Hussain MA, Porras DL, Rowe MH, West JR, Song WJ, Schreiber WE and Wondisford FE: Increased pancreatic beta-cell proliferation mediated by CREB binding protein gene activation. Mol Cell Biol 26: 7747-7759, 2006. 
51. Rütti S, Arous C, Nica AC, Kanzaki M, Halban PA and Bouzakri K: Expression, phosphorylation and function of the Rab-GTPase activating protein TBC1D1 in pancreatic beta-cells. FEBS Lett 588: 15-20, 2014

52. Khoury GA, Baliban RC and Floudas CA: Proteome-wide posttranslational modification statistics: Frequency analysis and curation of the swiss-prot database. Sci Rep 1: 1, 2011.

53. De León DD, Deng S, Madani R, Ahima RS, Drucker DJ and Stoffers DA: Role of endogenous glucagon-like peptide-1 in islet regeneration after partial pancreatectomy. Diabetes 52: 365-371, 2003.

54. Zhang X, Gaspard JP, Mizukami Y, Li J, Graeme-Cook F and Chung DC: Overexpression of cyclin D1 in pancreatic betacells in vivo results in islet hyperplasia without hypoglycemia. Diabetes 54: 712-719, 2005

55. Williams K, Abanquah D, Joshi-Gokhale S, Otero A, Lin H, Guthalu NK, Zhang X, Mozar A, Bisello A, Stewart AF, et al: Systemic and acute administration of parathyroid hormone-related peptide(1-36) stimulates endogenous beta cell proliferation while preserving function in adult mice. Diabetologia 54: 2867-2877, 2011
56. Alvarez-Perez JC, Ernst S, Demirci C, Casinelli GP Mellado-Gil JM, Rausell-Palamos F, Vasavada RC and Garcia-Ocaña A: Hepatocyte growth factor/c-Met signaling is required for $\beta$-cell regeneration. Diabetes 63: 216-223, 2014.

57. Gao L, Tang W, Ding Z, Wang D, Qi X, Wu H and Guo J: Proteinbinding function of RNA-dependent protein kinase promotes proliferation through TRAF2/RIP1/NF- $\kappa \mathrm{B} / \mathrm{c}-\mathrm{Myc}$ pathway in pancreatic $\beta$ cells. Mol Med 21: 154-166, 2015.

58. Andersson O, Adams BA, Yoo D, Ellis GC, Gut P, Anderson RM, German MS and Stainier DY: Adenosine signaling promotes regeneration of pancreatic $\beta$ cells in vivo. Cell Metab 15: 885-894, 2012.

59. Sakano D, Choi S, Kataoka M, Shiraki N, Uesugi M, Kume K and Kume S: Dopamine D2 receptor-mediated regulation of pancreatic $\beta$ cell mass. Stem Cell Reports 7: 95-109, 2016.

60. Mozar A, Lin H, Williams K, Chin C, Li R, Kondegowda NG, Stewart AF, Garcia-Ocaña A and Vasavada RC: Parathyroid hormone-related peptide (1-36) enhances beta cell regeneration and increases beta cell mass in a mouse model of partial pancreatectomy. PLoS One 11: e0158414, 2016. 